\title{
Meningkatkan Kompetensi Guru BK dalam Melaksanakan Layanan Bimbingan Klasikal melalui Supervisi Akademik
}

\author{
Hariyanto $^{(1)}$ \\ ${ }^{1}$ Dinas Pendidikan Kabupaten Blitar \\ Email: 1hariyanto.pengawas@yahoo.com \\ DOI: https://doi.org/10.28926/riset_konseptual.v2i4.86
}

\begin{abstract}
ABSTRAK
Penelitian ini bertujuan untuk mengetahui sejauh mana efektivitas pelaksanaan supervisi akademik dalam upaya meningkatkan kompetensi guru BK dalam melaksanakan layanan bimbingan klasikal di kelas pada sekolah binaan. Jenis penelitian ini adalah Penelitian Tindakan Sekolah (PTS) yang terselesaikan dalam dua siklus. Setiap siklusnya terdiri dari empat tahap yaitu perencanaan (planning), pelaksanaan (action), pengamatan (observation), dan refleksi (reflection). Penelitian tindakan sekolah ini dilaksanakan dalam dua siklus yang melibatkan guru bimbingan konseling SMPN 1 Kanigoro, SMPN 1 Wlingi dan SMPN 2 Wlingi Kabupaten Blitar dengan indikator keberhasilan $>90.0$. Penelitian ini diawali dengan pelaksanaan supervisi akademik pelaksanaan bimbingan klasikal kepada guru BK SMP sesuai dengan jadwal yang telah dibuat. Setelah dilakukan penelitian tindakan sekolah, dapat disimpulkan bahwa kompetensi guru BK melaksanakan program bimbingan konseling sangat penting dan wajib dilaksanakan di sekolah dan semua sekolah melaksanakan program bimbingan dan konseling yang direncanakan dan dibuat, walaupun masih ada guru yang berlatar belakang bukan bimbingan konseling.
\end{abstract}

Kata kunci: bimbingan klasikal, kompetensi guru, supervisi akademik,

\section{PENDAHULUAN}

Undang-undang RI No. 20 Tahun 2003 tentang Sistem Pendidikan Nasional pasal 4 menyatakan Pendidikan Nasional bertujuan mencerdaskan kehidupan bangsa dan mengembangk an manusia Indonesia seutuhnya, yaitu manusia yang beriman dan bertakwa terhadap Tuhan Yang Maha Esa dan berbudi pekerti luhur, memiliki pengetahuan dan keterampilan, kesehatan jasmani dan rohani, kepribadian yang mantap dan mandiri serta rasa tanggung jawab kemasyarakatan dan kebangsaan.

Berdasarkan keterangan pada Undang-undang tersebut di atas, satuan pendidikan sebagai wadah mengembangkan pendidikan yang terlibat langsung mewujudkan tujuan pendidikan tersebut harus menyelenggarakan pendidikan seoptimal mungkin sesuai dengan Peraturan Pemerintah Nomor 19 Tahun 2005 tentang Standar Nasional Pendidikan. Pelaksanaan Standar Nasional Pendidikan tersebut dituangkan dalam Peraturan Menteri Pendidikan Nasional, di antaranya Permendiknas Nomor 23 Tahun 2006 tentang Standar kompetensi Lulusan (SKL) yang menyebutkan bahwa standar kompetensi kelulusan satuan pendidikan dikembangkan berdasarkan tujuan satuan pendidikan, yaitu:

(1) Pendidikan Dasar, yang meliputi SD/MI/SDLB/Paket A dan SMP/MTs/SMPLB/Paket B; (2) Pendidikan Menengah, yang meliputi: SMA/MA/SMALB/ Paket C; dan Pendidikan Menengah Pertama, yang meliputi SMK/MAK. Dalam Permendiknas Nomor 23 ini juga menyebutkan bahwa tujuan satuan pendidikan dasar adalah meletakkan dasar kecerdasan, pengetahuan, kepribadian, akhlak mulia, serta keterampilan untuk hidup mandiri dan mengikuti pendidikan lebih lanjut. Untuk mencapai tujuan tersebut maka kompetensi kompetensi dan tujuan yang telah ditetapk an sesuai amanah Permendiknas Nomor 22 Tahun 2006 tentang Standar Isi harus dijabarkan melalui setiap mata pelajaran yang terdapat dalam struktur kurikulum pendidikan dasar untuk dikuasai, dipahami dan diimplementasikan oleh peserta didik dalam kehidupan s ehari-harinya. 
Vol. 2 No. 4, Oktober 2018;

Pencapaian tujuan satuan pendidikan tersebut diaktualisasikan guru dalam proses pembelajaran sesuai dengan amanah Permendiknas Nomor 41 Tahun 2007 tentang Standar Proses. Guru adalah salah satu komponen paling penting dalam upaya pencapaian tujuan pendidikan karena guru merupakan ujung tombak pelaksanaan suatu program pendidikan yang dilakukan pada kegiatan pembelajaran di kelas. Oleh sebab itu, tinggi rendahnya kualitas guru dalam pembelajaran mempengaruhi tinggi rendahnya keberhasilan tujuan pembelajaran. Kegiatan pembelajaran akan berjalan dengan baik dan bisa mencapai tujuan yang diharapkan jika guru memiliki kompetensi pada bidang yang diajarkannya.

Kompetensi yang harus dimiliki oleh setiap guru yang profesional berdasarkan Peraturan Menteri Pendidikan Nasional Republik Indonesia Nomor 16 Tahun 2007 tentang Standar Kualifikasi Akademik dan Kompetensi Guru menyebutkan bahwa Standar Kompetensi Guru dikembangkan secara utuh dari 4 kompetensi utama, yaitu: (1) kompetensi pedagogik, (2) kepribadian, (3) sosial, dan (4) profesional. Guru yang profesional dituntut mampu mengembangkan dan mengelola proses pembelajaran demi mencapai tujuan pembelajaran. Proses pembelajaran itu sendiri meliputi; merencanakan pembelajaran, melaksanakan pembelajaran, melakukan penilaian pembelajaran dan melakukan tindak lanjut sesuai dengan Standar Proses dan Standar Penilaian Pendidikan.

Kegiatan pembelajaran yang kondusif, dan pelaksanaan bimbingan yang terarah pada peserta didik, merupakan komponen penting yang harus dilaksanakan dalam rangka pencapaian tujuan sekolah. Sekolah yang kondusif adalah sekolah yang melaksanakan program bimbingan konseling dengan baik (Usman, 1995). Dengan dilaksanakannya empat bidang bimbingan baik bimbingan pribadi, bimbingan sosial, bimbingan belajar, dan bimbingan karir serta dilaksanakannya pemberian layanan baik layanan orientasi, layanan informasi, layanan penempatan, layanan penguasaan konten, layanan konseling perorangan, kelompok, bimbingan pribadi, layanan konsultasi, dan layanan mediasi, maka siswa akan mampu mengatasi masalah dirinya secara optimal . Pada sekolah (SMPN) binaan yang penulis adakan penelitian, guru BK nya yang melaksanakan layanan bimbingan dan konseling di sekolah sudah terjadwal masuk kelas secara rutin. Berdasarkan hasil analisis data empiric temuan pengawas BK di Sekolah Menengah Pertama Negeri menemukan kondisi kurang optimal dalam pelaksanaan layanan bimbingan klasikal. Berdasarkan data-data yang ada beberapa guru BK yang 1) melakukan layanan bimbingan klasikal jam terjadwal tetapi tidak terlak sana dengan baik, 2) melakukan bimbingan klasikal tetapi tanpa Rencana Pelaksanaan Layanan (RPL) ,3) hanya menggunakan metode ceramah sehingga layanan tampak monoton oleh penjelasan guru BK ,4) tanpa penilaian proses layanan sehingga kurang dapat diketahui tingkat keberhasilan layanan dan 5) tanpa memanfaatkan media dan lembar kerja sehingga pencapaian tujuan layanan kurang signifikan. Sehingga hal ini menjadikan proses layanan yang kurang menyenangkan. Dimungkinkan fakta tersebut menyebabkan timbulnya keengganan guru BK dalam melaksanakan bimbingan klasikal. Dari sekolah-sekolah yang menjadi binaan penulis ada tiga sekolah yang sudah terjadwal untuk masuk kelas melaksanakan layanan bimbingan klasikal yaitu SMPN 1 Kanigoro, SMPN 1 Wlingi, dan SMPN 2 Wlingi Kabupaten Blitar. Dari hasil pemantauan dan penilaian peneliti selaku pengawas dalam kegiatan kepengawasan, meman g guru kurang mengembangkan proses pelaksanaan layanan bimbingan klasikal, baik pada perencanaan dan pelaksanaan pelayanan bimbingan klasikal, guru BK masih dominan menggunakan metode ceramah di kelas. Dari hasil supervisi akademik peneliti selaku pengawas sekolah diperoleh informasi bahwa meskipun di dokumen RPL tertulis metode pembelajaran modeling, role play atau yang lain tetapi dalam praktek di kelas tetap menggunakan ceramah. Dominannya guru BK menggunak an metode ceramah dalam kegiatan layanan bimbingan klasikal di kelas diduga 
menjadi salah satu penyebab kurangnya minat dan antusias peserta didik dalam mengikuti layanan bimbingan klasikal dan tidak tidak tercapainya perubahan sikap dari peserta didik khususnya pada perubahan tingkah laku. Hal ini mendorong peneliti melakukan perbaikan proses layanan bimbingan klasikal dengan meningkatkan kompetensi guru BK dalam menggunakan metode dan model pembelajaran yang lebih inovatif dalam proses layanan bimbingan klasikal. Salah satu upaya pembinaan dan bimbingan yang dilakukan peneliti untuk meningkatkan k ompetensi guru BK dalam proses pembelajaran melalui kegiatan supervisi akademik yang dilakukan oleh pengawas Pembina dan berkesinambungan . Karena dengan supervisi akademik ini guru BK bisa mengetahui sejauh mana kompetensi yang dimiliki dan memberi informasi untuk mengembangkan model -model pembelajaran yang lebih inovatif, menentukan materi layanan yang sesuai dengan kondisi kelas atau sekolah masing-masing.

Dengan kondisi yang seperti tersebut di atas perlu dilakukan tindakan dari pengawas agar guru BK dapat melaksanakan layanan bimbingan klasikal di sekolah dengan melaksanakan supervisi akademik kepada guru BK.

Daresh,1989,Glickman,et al 2007 dalam Pusat Pengembangan Tenaga Kependidikan Badan Pengembangan Sumber Daya Manusia Pendidikan Dan Kebudayaan Dan Penjaminan Mutu Pendidikan Kementrian Pendidikan Dan Kebudayaan(20 14:3) mendefinisikan supervisi akademik adalah serangkaian kegiatan untuk membantu guru mengembangkan kemampuannya mengelola proses pembelajaran demi pencapaian tujuan pembelajaran. Dengan demikian berarti esensi supervisi akademik bukan menilai unjuk kerja guru BK dalam mengelola proses layanan ,melainkan membantu guru BK mengembangkan kemampuan profesionalismenya terutama dalam melaksanakan layanan bimbingan klasikal di kelas binaannya.

Rumusan masalah dalam penelitian ini yaitu:"Apakah pelaksanaan super visi akademik mampu meningkatkan kompetensi guru BK dalam melaksanakan layanan bimbingan klasikal di SMP Negeri Binaan Kabupaten Blitar".

\section{METODE}

Penelitian ini menggunakan metode penelitian Tindakan Sekolah. Prosedur Penelitian Tindakan menurut Arikunto (2009) secara garis besar terdapat 4 tahapan yang lazim dilalui yaitu (1) Perencanaan, (2) Pelaksanaan, (3) Pengamatan, dan (4) Refleksi.

Alat pengumpul data yang dipergunakan dalam penelitian ini adalah: catatan peneliti, lembar wawancara untuk guru dan lembar instrumen untuk menganalisis RPL serta lembar pengamat an kegiatan layanan bimbingan yang mengungkapkan pelaksanaan layanan bimbingan klasikal dalam kegiatan di kelas. Data yang telah terkumpul akan dianalisis secara deskriptif dengan menggunak an teknik persentasi untuk mengetahui peningkatan yang terjadi dalam peningkatan kompetensi guru bimbingan konseling (BK) dalam melaksanakan layanan bimbingan klasikal melalui supervisi akademik di kelas.

Subyek penelitian sejumlah 10 orang guru bimbingan konseling (BK) dari sekolah binaan dalam hal ini SMPN 1 Kanigoro, SMPN 1 Wlingi dan SMPN 2 Wlingi. Penelitian tindakan sekolah dilaksanakan di SMP Negeri wilayah binaan Kabupaten Blitar , yaitu : 1) SMP Negeri 1 Kanigoro, 2) SMP Negeri 1 Wlingi, dan 3) SMP Negeri 2 Wlingi. Pe nelitian tindakan sekolah (PTS) dilaksanakan pada bulan 7 September sampai dengan 30 November 2015.

\section{HASIL \\ Siklus I}

\section{Perencanaan Tindakan}

Pada tahap ini peneliti menyiapkan instrumen penelitian yang terdiri dari; lembar wawancar a tertulis yang digunakan untuk mengetahui sejauh mana 
pemahaman guru BK mengenai pelaksanaan layanan bimbingan klasikal, lembar pengamatan dokumen RPL untuk menganalisis RPL yang menggali aspekaspek yang harus ada dalam rencana pelaksanaan layanan dan lembar pengamat an kegiatan supervisi akademis yang berisi pernyataan-pernyataan yang mengungkapkan langkah- langkah apa yang dilakukan dan yang tidak dilakukan dalam proses pelaksanaan layanan bimbingan klasikal. Selain itu juga dipersiapkan bahan bimbingan bagi guru bimbingan konseling untuk meningkatkan kompetensi guru BK dalam melaksanakan layanan bimbingan klasikal.

\section{Pelaksanaan Tindakan}

Pelaksanaan tindakan untuk siklus 1 dilaksanakan di SM P Negeri 1 Kanigoro pada tanggal 7 September 2015. Pelaksanaan supervisi pada empat (5) orang guru bimbingan konseling di SMPN 1 Kanigoro dalam melaksanakan layanan bimbingan klasikal di kelas dengan menggunakan lembar instrumen supervisi akademik. Guru bimbingan konseling yang di supervisi akademis yaitu Drs. Purwanto, Imam Muslih, S.Pd, Sukino,S.Pd ,Rudi Astutik, S.Pd, dan Lilik Suherlien ,S.Pd . Pada kesempatan ini peneliti memberikan lembar pengamatan RPL untuk guru BK yang bertujuan mengungkap langkah - langkah yang digunakan guru BK dalam kegiatan bimbingan klasikal di kelas. Dari hasil pengamat an ini peneliti melihat bahwa guru BK masih cenderung menggunakan metode ceramah seperti hasil sementara peneliti saat supervisi akademik. Oleh sebab itu peneliti selaku pengawas memberikan wawasan pengetahuan perihal metode dan model pelaksanaan layanan bimbingan klasikal, dengan harapan bimbingan klasikal yang dilaksanakan dapat diterima dengan baik oleh peserta didik di SMPN 1 Kanigoro sesuai dengan kondisi sekolah masing-masing. Setelah pemberian materi bimbingan dilanjutkan dengan menyusun rencana pelaksanaan layanan (RPL).

Pada tanggal 14 September 2015 mengadakan supervisi akademis di SMPN 1 Wlingi, tempat kegiatan di SMP Negeri 1 Wlingi. Guru BK yang di supervisi: Dra. Endang Eko Winarsih, Dra. Sri Hidajati, Seger S.Pd . Dalam pertemuan ini guru BK melakukan kegiatan bimbingan klasikal di kelas sesuai dengan jadwal yang telah ada dengan membuat RPL yang sudah disusun guru bimbingan konseling (BK).

Pada tanggal 17 September 2015 mengadakan supervisi akademis di SMPN 2 Wlingi ,tempat kegiatan di SMP Negeri 2 Wlingi. Guru BK yang di supervisi: Minus Suprayitno,S.Pd, dan Arin Dewi Kurniasari,S.Pd. .Dalam pertemuan ini guru BK melakukan kegiatan bimbingan klasikal di kelas sesuai dengan jadwal yang telah ada dengan membuat RPL yang sudah disusun guru bimbingan konseling (BK).

Pada kesempatan ini peneliti mengumpulkan copy RPL dari semua guru BK yang sudah di supervisi akademik untuk dianalisis .

\section{Observasi (Pengamatan)}

Pengamatan terlaksana antara tanggal 21 September 2015 sampai dengan tanggal 6 Oktober 2015. Pengamatan dilakukan dari analisis dokumen rencana pelaksanaan layanan (RPL) oleh peneliti sendiri dan pengamatan kegiatan pelaksanaan layanan bimbingan klasikal di sekolah masing-masi $\mathrm{n} g$ guru bimbingan konseling dilakukan dengan menggunakan lembar pengamatan kegiatan pelaksanaan layanan bimbingan klasikal. Namun karena tugas dan kegiatan lain dari peneliti tidak semua guru bimbingan konseling di sekolah binaan bisa peneliti supervisi.

\section{Siklus II}

\section{Perencanaan Tindakan}

Pada tahap ini peneliti masih menyiapkan instrumen penelitian yang terdiri dari lembar pengamatan kegiatan layanan bimbingan klasikal dan lembar pengamatan dokumen RPL seperti pada siklus 1 . Selain itu berdasar hasil evaluasi 
dan refleksi siklus 1 peneliti juga masih mempersiapkan bahan bimbingan tentang metode pelaksanaan layanan bimbingan klasikal dan mengimplementasikannya dalam rencana pelaksanaan layanan untuk memperkuat pemahaman guru BK. Menurut peneliti penyusunan disain rencana pelaksanaan layanan sangat menentukan keberhasilan seorang guru bimbingan konseling dalam melaksanakan layanan bimbingan klasikal di kelas, maka menyiapkan tahapan langkah kegiatan sesuai metode dan tujuan dalam penyusunan RPL sangat diperlukan. Rencana Pelaksanaan Layanan yang penerapannya akan menjadikan bimbingan klasikal menjadi bermakna, aktif, kreatif dan efektif dan menyenangkan dengan menghubungk an materi yang didapat dengan situasi nyata di lingkungan dan kehidupan sehari - hari serta memberi kecakapan hidup bagi peserta didik.

\section{Pelaksanaan Tindakan}

Pelaksanaan tindakan untuk siklus 2 dilakukan supervisi akademik sesuai rencana pada guru BK di SMP Negeri 1 Kanigoro pada tanggal 19 Oktober 2015. Pada kesempatan ini peneliti menyampaikan hasil evaluasi dan refleksi kepada guru BK, baik hasil pengamatan kegiatan layanan bimbingan klasikal ataupun hasil analisis dokumen RPL. Berbekal kekurangan-kekurangan yang ditemukan pada siklus 1 peneliti mendorong guru BK untuk lebih memahami langkah -langkah dalam melaksanakan layanan bimbingan klasikal. Dengan bimbingan ini guru BK bisa lebih memilih metode layanan yang disesuaikan dengan indikator dan materi layanan, serta bagaimana menyusun tahapan langkah kegiatan layanan bimbingan klasikal. Selain itu peneliti juga meminta guru BK menyiapkan media belajar untuk membantu peserta didik memahami dan menguasai materi layanan sesuai indikator dan tujuan dari layanan.

Pada tanggal 27 Oktober 2015 melaksanakan supervisi akademik pada guru BK , tempat kegiatan di SMPN 1 Wlingi. Seperti pelaksanaan tindakan pada siklus 1 dalam pertemuan ini guru bimbingan konseling melakukan kegiatan layanan bimbingan klasikal di kelas yang sudah terjadwal dengan materi yang sesuai di RPL yang sudah disusun.

Pada tanggal 3 November peneliti melaksanakan supervisi akademik kepada guru BK di SMP Negeri 2 Wlingi. Seperti pelaksanaan tindakan pada siklus 1 dalam pertemuan ini guru bimbingan konseling melakukan kegiatan layanan bimbingan klasikal dengan materi yang sesuai di RPL yang sudah disusun di kelas yang sudah terjadwal.

Peneliti juga mengumpulkan copy RPL yang sudah direvisi dari seluruh guru bimbingan konseling untuk dianalisis dan juga meminta bisa menerapkan dalam kegiatan layanan bimbingan klasikal di kelasnya.

\section{Ob servasi (Pengamatan)}

Pengamatan terlaksana antara tanggal 5 November 2015 sampai dengan tanggal 16 November 2015. Pengamatan dengan melakukan analisis dokumen RPL oleh peneliti sendiri. Untuk pengamatan kegiatan layanan bimbingan klasikal dilakukan dengan menggunakan lembar pengamatan kegiatan layanan yang sudah disiapkan. Peneliti berusaha melakukan pengamat an kegiatan layanan bimbingan klasikal langsung di kelas, tetapi bila ada tugas dan kegiatan lain yang bersamaan dari peneliti tidak semua sekolah bisa peneliti kunjungi untuk melakukan pengamat an langsung di kelas, solusi yang diambil peneliti meminta bantuan salah satu guru yang lebih senior untuk menjadi pengamat

\section{PEMBAHASAN}

Pada awalnya pelaksanaan siklus 1 dalam pelaksanaan supervisi akademis belum sesuai dengan rencana peneliti, karena guru yang di supervisi belum terbiasa dengan langkah-langkah yang tercantum dalam RPL nya, 
Vol. 2 No. 4, Oktober 2018;

pelaksanaan supervisi akademis terasa kaku dan terkesan kurang serius. Setelah diberi penjelasan dan bimbingan selanjutnya kegiatan supervisi akademis dapat berjalan lebih baik seperti yang direncanakan.

Secara umum kemampuan guru BK dalam melaksanakan layanan bimbingan kelompok mengalami peningkatan, kekurangan-kekurangan yang terdapat pada siklus pertama ini akan dijadikan pertimbangan untuk perbaikan pada siklus kedua.

Pelaksanaan simulasi pada siklus 2 lebih lancar dibandingkan siklus 1 sesuai dengan harapan peneliti, guru bimbingan konseling mulai terbiasa dengan langkah-langkah dalam melaksanakan layanan bimbingan klasikal. Hal ini disebabkan semua guru BK yang terlibat dalam kegiatan supervisi akademik mengetahui peran dan tanggung jawabnya masing-masing. (1) Dari hasil supervisi akademik mendorong guru BK untuk melaksanakan kegiatan layanan bimbingan klasikal di kelas sesuai dengan jadwal, seperti yang direncanakan dalam RPL walaupun masih ada guru BK yang perlu pembinaan khusus. Perolehan nilai hasil pengamat an layanan bimbingan klasikal pada siklus 2 ini bisa dilaporkan bahwa; 3 orang guru BK berpredikat Amat baik, 6 orang guru BK berpredikat Baik, 1 orang guru BK berpredikat Cukup. (2) Dari hasil analisis dokumen rencana pelaksanaan layanan (RPL) diketahui bahwa pemaham an dan kemampuan guru BK dalam menyusun serta mengembangkan RPL sudah lebih berkembang. Keinginan guru untuk meningkatkan kemampuan kompetensi guru bimbingan konseling dalam pengembangan pelaksanaan layanan cukup tinggi, hal ini tercermin dari berbagai pertanyaan yang diajukan saat peneliti mendampingi penyusunan RPL pada kegiatan supervisi akademik berlangsung. Meskipun pada siklus 2 telah terjadi peningkatan kom petensi guru BK dalam merencanakan dan mengembangkan RPL, namun masih ada yang belum sepenuhnya dikuasai guru BK.

\section{KESIMPULAN}

Berdasarkan hasil pengamatan dan analisis data yang telah dilakukan dari 2 siklus dalam kegiatan Penelitian Tindakan Sekolah dapat disimpulkan, bahwa: 1) Melalui bimbingan pengawas dengan supervisi akademik dapat meningkatkan kompetensi guru bimbingan konseling (BK) dalam pelaksanaan layanan bimbingan klasikal, 2) Kemampuan guru bimbingan konseling dalam menyusun dan mengembangkan RPL dari siklus 1 dan siklus 2 menunjukkan peningkatan, hal ini tercermin dari hasil rekapitukasi kualifikasi nilai analisis dokumen RPL, 3) Dari hasil observasi memperlihatkan bahwa terjadi peningkatan jumlah guru bimbingan konseling yang melaksanakan kegiatan bimbingan klasikal sesuai dengan RPL yang dibuat dalam kegiatan layanan, yaitu pada kondisi awal 7 guru bimbingan konseling $(70 \%)$ pada siklus 1, dan meningkat lagi menjadi 10 orang guru (100\%) pada siklus 2 .

\section{SARAN}

Berdasarkan kesimpulan yang telah diambil, sebaiknya dalam melaksanakan penelitian tindakan sekolah dapat kerjasama dengan pengawas dan supervisi akademik untuk meningkatkan hasil yang baik danguna kompetensi guru.

\section{DAFTAR RUJUKAN}

Departemen Pendidikan Nasional Republik Indonesia . 2007. Peraturan Menteri Pendidikan Nasional Republik Indonesia Nomor 16 Tahun 2007 Tentang Standar Kualifikasi dan Kompetensi Tenaga Pendidik. Jakarta: Departemen Pendidikan Nasional.

Jenderal PMPTK. 2007. Kumpulan Materi Bimbingan Teknis Peningkatan Kompetensi Pengawas Sekolah, Jakarta: Departemen Pendidikan Nasional. 
JURNAL PENDIDIKAN: Riset \& Konseptual

Vol. 2 No. 4, Oktober 2018;

Departemen Pendidikan Nasional Republik Indonesia .2007.Peraturan Menteri Pendidikan Nasional Republik Indonesia Nomor 20 Tahun 2007 Tentang Standar Penilaian Pendidikan. Jakarta : Departemen Pendidikan Nasional.

Suharsimi Arikunto. 2009. Penelitian Tindakan untuk Guru, Kepala Sekolah \& Pengawas. Yogyakarta: Adiyta Media. 